\title{
RELATIONSHIP OF SERUM CALCIUM LEVEL WITH BASAL METABOLIC INDEX \& HIP CIRCUMFERENCE IN OBESE FEMALES OF REPRODUCTIVE AGE
}

\author{
AKTER ${ }^{1}$, AKHTER QS ${ }^{2}$, HOSSAIN MZ $^{3}, \mathrm{DEB} \mathrm{SR}^{4}, \mathrm{KHAN} \mathrm{MH}^{5}$, SHAHJADI ${ }^{6}$, BEGUM R ${ }^{7}$
}

\begin{abstract}
:
Background: Obesity is a common health problem in urban population now-a-days.

Objective: The present study was carried out to asses the relationship of serum calcium levels with obesity.

Methods: This cross sectional study was done in Department of Physiology, Dhaka Medical College, Dhaka. For this purpose, 120 subjects within the age range of 25 to 50 years of both sexes were included in the study. Among them 60 non-obese, apparently healthy subjects were selected as control (Group A) and 60 obese subjects as case (Group B). Group A was further subdivided as group $A_{1}$ (non-obese male) \& group $A_{2}$ (non-obese female). Group $B$ was further subdivided as group $B_{1}$ (obese male) \& group $B_{2}$ (obese female). Case and control subjects were selected from the Urban Primary Health Care Project (UPHCP), PA-2, Dhaka City Corporation, Dhaka, and by personal contact during the period from January 2010 to December 2010. All the subjects were apparently healthy. Post menopausal women were excluded.
\end{abstract}

Results: In this study, serum total calcium level was significantly and positively related with $B M I \&$ Hip $C$ in group $B_{2}(r=+0.397,+0.407 ; p=0.030,+0.026)$.

Conclusion: This study concludes that, serum calcium level increases with increase in BMI \& Hip circumference in females of reproductive age.

Keywords: Serum total calcium level, Basal Metabolic Index (BMI), Hip Circumference.

J Dhaka Med Coll. 2011; 20(2) : 141-145.

\section{Introduction}

Overweight and obesity are important determinants of health and lead to adverse metabolic changes. Obesity is a predisposing factor for poor health and also a cause of increased mortality. ${ }^{1}$

Globally, there are more than 1 billion overweight adult people, at least 300 million of them are obese. Obesity has reached epidemic proportions. ${ }^{2}$ Basal Metabolic Index (BMI) greater than 30 is defined as "obesity". ${ }^{3}$ As many as 30 health conditions are associated with obesity, including heart disease, diabetes, high blood pressure, stroke and some forms of cancer. ${ }^{4}$ World health report 2002 states, approximately $58 \%$ of diabetes, $21 \%$ of ischemic heart disease and $8-42 \%$ of certain cancers globally were attributable to a BMI above $21 \mathrm{~kg} /$ $\mathrm{m}^{2} \cdot{ }^{2}$

It is also correlated with an increased risk of death. The relationship between obesity and associated morbidities is stronger among individuals younger than 55 years. ${ }^{5}$ It has been proved that obesity is influenced by genetic, chemical, environmental and behavioral factors. ${ }^{5}$

High level of calcium in the blood can be dangerous to a number of cells, including the

1. Dr. Nurjahan Akter N, Lecturer, Department of Physiology, Dhaka National Medical College, Dhaka

2. Dr. Qazi Shamima Akhter, Professor and Head, Department of Physiology, Dhaka Medical College, Dhaka

3. Dr. Md. Zaid Hossain, Assistant Professor, Department of Medicine, Dhaka Medical College, Dhaka

4. Dr. Sudip Ranjan Deb, Resident Physician, Dhaka Medical College Hospital, Dhaka.

5. Dr. Mosaraf Hossain Khan, Registrar, Department of Nephrology, Dhaka Medical College,

6. Dr. Shorifa Shahjadi, Assistant Professor, Department of Physiology, MARKS Medical College, Dhaka

7. Dr. Rokeya Begum, Professor and Head, Department of Physiology, Enam Medical College, Savar, Dhaka

Correspondence: Dr. Nurjahan Akter, Lecturer, Department of Physiology, National Medical College, Dhaka.

Cell Phone: +8801726528999. 
lining of the stomach and the pancreas, causing both of these organs to become inflamed and painful (ulcers and acute pancreatitis $)^{6}$.

Common presentation for persistently elevated calcium levels is the development of kidney stones. Since the major function of the kidney is to filter and clean the blood, they will be constantly exposed to high levels of calcium in patients with hyperparathyroidism.

Positive correlations between plasma calcium, BMI and waist circumference, and also between PTH, BMI and waist circumference have been found. ${ }^{7}$ The increased intracellular calcium is an important second messenger that triggers various pathways that promote the accumulation of fat in adipose tissue, including activation of lipogenesis by augmenting fatty acid synthase activity. ${ }^{8-9}$

\section{Methods}

The present cross-sectional study was done in the Department of Physiology, Dhaka Medical College, Dhaka, from January to December 2010. 120 subjects were selected within the age range of 25-50 years. Among them 60 nonobese, apparently healthy subjects were selected as control (Group A) and 60 obese subjects as case (Group B). Group A was further subdivided as group $A_{1}$ (non-obese male) \& group $A_{2}$ (non-obese female). Group $B$ was further subdivided as group $\mathrm{B}_{1}$ (obese male) \& group $\mathrm{B}_{2}$ (obese female).

Non-obese $\left(\mathrm{BMI}<30 \mathrm{Kg} / \mathrm{m}^{2}\right)$ and obese $(\mathrm{BMI}>30$ $\mathrm{Kg} / \mathrm{m}^{2}$ ) subjects of both male and female sex were included. Postmenoposal women, pregnant women, persons suffering from Hypo/ Hyperparathyroidism, chronic kidney disease, having history of Thyroidectomy \& parathyroidectomy and oral calcium vitamin D \& supplementation were excluded from the study.

Sample was collected in fasting condition and anthropometric measurements were taken after evacuation of bowel and bladder. Serum total calcium was measured by bichromatic endpoint technique in Dimension ${ }^{\circledR}$ clinical chemistry system.
Statistical analyses were performed by using SPSS for windows version 11.0. Comparison between two groups were done by using Student's unpaired ' $t$ ' test. Correlation analysis was done by using Pearson's correlation test. $\mathrm{P}$ value $<0.05$ was taken as level of significance.

\section{Results}

BMI: The Mean+SD of BMI were 24.08+2.88, $23.25+1.42,33.57+4.05,35.14+4.19 \mathrm{~kg} / \mathrm{m}^{2}$ in group $A_{1}, A_{2}, B_{1} \& B_{2}$ respectively. The $B M I$ in group $B_{1}$ was higher than that of group $A_{1}$ and group $B_{2}$ was higher than group $A_{2}$ which were statistically significant $(\mathrm{P}<0.001)$ (Table-I).

Hip circumference: The Mean+SD of hip circumference were $80.33+5.17,93.73+8.40$, $96.77+9.81,105.53+6.51 \mathrm{~cm}$ in group $\mathrm{A}_{1}, \mathrm{~A}_{2}, \mathrm{~B}_{1}$ $\& B_{2}$ respectively. The hip circumference in group $B_{1}$ was higher than group $A_{1}$ and in group $B_{2}$ Hip $C$ was higher than group $A_{2}$ which were statistically significant $(\mathrm{P}<0.001)$ (Table-II).

Table I

Mean $( \pm S D) B M I\left(\mathrm{~kg} / \mathrm{m}^{2}\right)$ in different groups $(n=120)$

\begin{tabular}{ccc}
\hline Groups & $\mathrm{n}$ & Mean $\pm \mathrm{SD}$ \\
\hline $\mathrm{A}_{1}$ & 30 & $24.08 \pm 2.88$ \\
$\mathrm{~A}_{2}$ & 30 & $23.25 \pm 1.42$ \\
$\mathrm{~B}_{1}$ & 30 & $33.57 \pm 4.05$ \\
$\mathrm{~B}_{2}$ & 30 & $35.14 \pm 4.19$
\end{tabular}

\begin{tabular}{lccc}
\hline Groups & $\mathrm{t}$ & $\mathrm{df}$ & $\mathrm{p}$ value \\
\hline $\mathrm{A}_{1}$ vs B $_{1}$ & 11.632 & 58 & $0.0001^{* * *}$ \\
$\mathrm{~A}_{2}$ vs B $_{2}$ & 14.706 & 58 & $0.0001^{* * *}$ \\
\hline
\end{tabular}

The results are expressed as Mean \pm SD. Unpaired Student's 't' test was performed to compare between groups. The test of significance was calculated and $p$ values $<0.05$ was accepted as level of significance.

\begin{tabular}{|c|c|c|c|}
\hline Group $A_{1}$ & : Nonobese male & $\mathrm{n}$ & $\begin{aligned}= & \text { Number of } \\
& \text { subjects }\end{aligned}$ \\
\hline Group $\mathrm{A}_{2}$ & : Nonobese female & $\mathrm{df}$ & $\begin{aligned}= & \text { Degree of } \\
& \text { freedom }\end{aligned}$ \\
\hline Group $B_{1}$ & : Obese male & $* * *$ & $\begin{array}{r}=\text { Significant at } \\
\text { p }<0.001 \text { level }\end{array}$ \\
\hline Group $B_{2}$ & : Obese female & & \\
\hline
\end{tabular}


Table II

Mean $( \pm S D)$ hip circumference $(\mathrm{cm})$ in different groups $(n=120)$

\begin{tabular}{lccc}
\hline Groups & $\mathrm{n}$ & & Mean $\pm \mathrm{SD}$ \\
\hline $\mathrm{A}_{1}$ & 30 & & $80.33 \pm 5.17$ \\
$\mathrm{~A}_{2}$ & 30 & & $93.73 \pm 8.40$ \\
$\mathrm{~B}_{1}$ & 30 & & $96.77 \pm 9.81$ \\
$\mathrm{~B}_{2}$ & 30 & & $105.53 \pm 6.51$ \\
\hline Groups & $\mathrm{t}$ & $\mathrm{df}$ & $\mathrm{p}$ value \\
\hline $\mathrm{A}_{1}$ vs $\mathrm{B}_{1}$ & 8.117 & 58 & $0.0001^{* * *}$ \\
$\mathrm{~A}_{2}$ vs $\mathrm{B}_{2}$ & 6.085 & 58 & $0.0001^{* * *}$ \\
\hline
\end{tabular}

The results are expressed as Mean \pm SD. Unpaired Student's ' $\mathrm{t}$ ' test was performed to compare between groups. The test of significance was calculated and $p$ values $<0.05$ was accepted as level of significance.

\begin{tabular}{lll}
\hline Group $\mathrm{A}_{1}:$ Nonobese male $\mathrm{n}=$ & Number of \\
& subjects \\
Group $\mathrm{A}_{2}:$ Nonobese female $\mathrm{df}=$ & $\begin{array}{l}\text { Degree of } \\
\text { freedom }\end{array}$ \\
Group $\mathrm{B}_{1}:$ Obese male & $* * *=$ & Significant at \\
& $\mathrm{p}<0.001$ level
\end{tabular}

Correlation of serum total calcium level with BMI of different groups: In group $B_{1}$ and $A_{1}$ serum total calcium level showed negative correlation ( $\mathrm{r}=-0.174,-0.260)$ with BMI. In group $B_{2}$ and group $A_{2}$ showed positive correlation $(\mathrm{r}=+0.397,+0.349)$ with $\mathrm{BMI}$ but these relationships were statistically non significant in all the groups (Table-III, Fig. 1,2).

Table III

Correlation between BMI and serum calcium in different groups $(n=120)$

\begin{tabular}{cccc}
\hline Groups & $\mathrm{n}$ & $\mathrm{r}$ value & $\mathrm{p}$ value \\
\hline $\mathrm{A}_{1}$ & 30 & 0.260 & $0.165^{\mathrm{ns}}$ \\
$\mathrm{B}_{1}$ & 30 & 0.174 & $0.357^{\mathrm{ns}}$ \\
$\mathrm{A}_{2}$ & 30 & +0.349 & $0.059^{\mathrm{ns}}$ \\
$\mathrm{B}_{2}$ & 30 & +0.397 & $0.030^{*}$ \\
\hline
\end{tabular}

Pearson correlation test was performed to compare relationship between parameters.
The test of significance was calculated and $\mathrm{p}$ values $<0.05$ was accepted as level of significance.

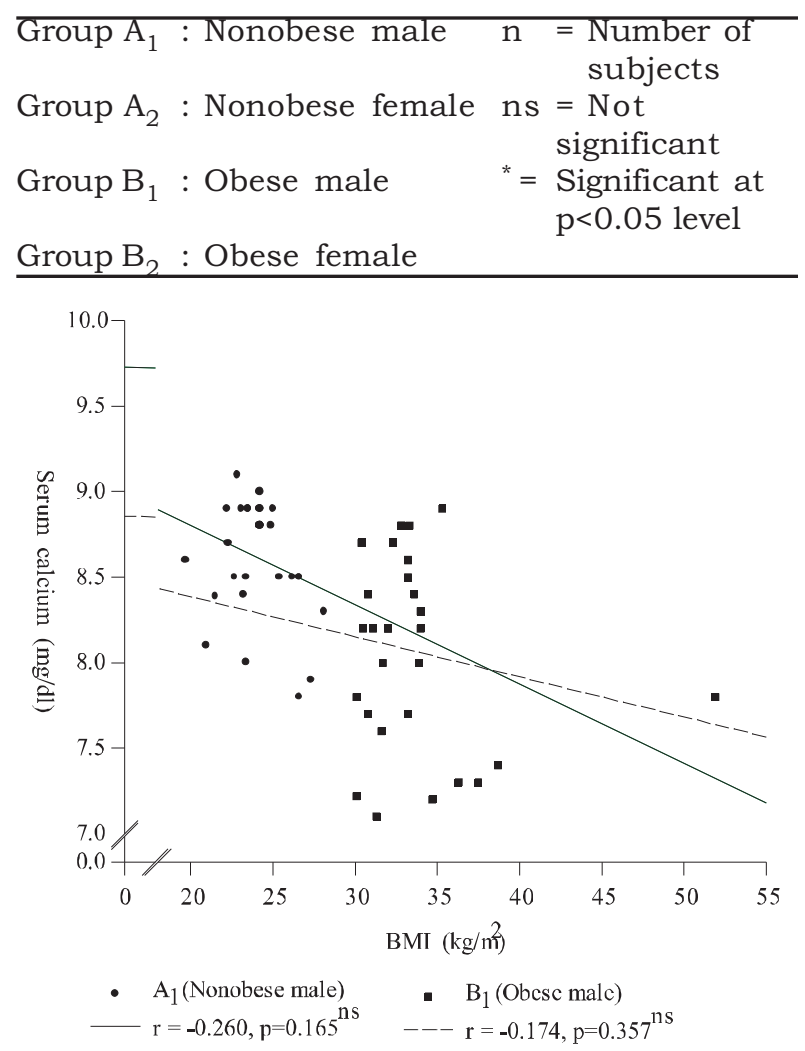

Fig.-1: Correlation between serum calcium with BMI in male

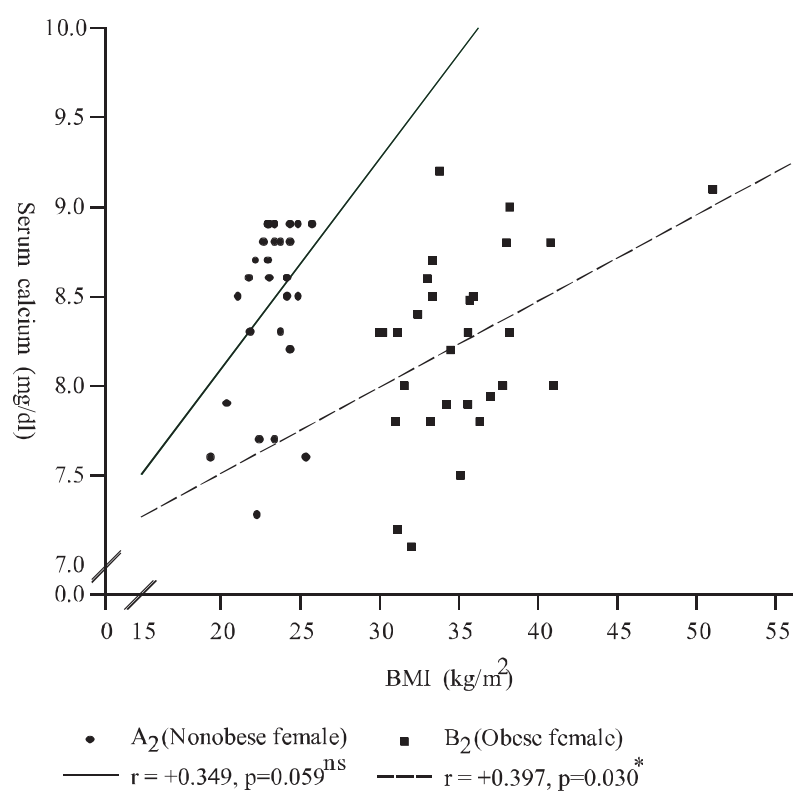

Fig.-2: Correlation between serum calcium with $B M I$ in female 
Correlation of serum total calcium level with hip circumference of different groups: In group $\mathrm{B}_{2}$ serum total calcium level showed significant positive correlation $(r=+0.407)$ with hip circumference. In group $B_{1}$ showed statistically non-significant negative correlation ( $\mathrm{r}=-0.108)$ but in group $\mathrm{A}_{1}$ and $\mathrm{A}_{2}$ showed positive correlation $(\mathrm{r}=+0.307,+0.053)$ with hip circumference but these relationships were statistically non significant in both groups (Table-IV, Fig. 3,4).

Table IV

Correlation between hip circumference and serum calcium in different groups $(n=120)$

\begin{tabular}{cccc}
\hline Groups & $\mathrm{n}$ & $\mathrm{r}$ value & $\mathrm{p}$ value \\
\hline $\mathrm{A}_{1}$ & 30 & +0.307 & $0.099^{\mathrm{ns}}$ \\
$\mathrm{B}_{1}$ & 30 & 0.108 & $0.569^{\mathrm{ns}}$ \\
$\mathrm{A}_{2}$ & 30 & +0.053 & $0.781^{\mathrm{ns}}$ \\
$\mathrm{B}_{2}$ & 30 & +0.407 & $0.026^{*}$ \\
\hline
\end{tabular}

Pearson correlation test was performed to compare relationship between parameters.

The test of significance was calculated and $p$ values $<0.05$ was accepted as level of significance.

\begin{tabular}{llll}
\hline Group $\mathrm{A}_{1}$ & $:$ Nonobese male & $\mathrm{n}$ & $\begin{array}{l}\text { Number of } \\
\text { subjects }\end{array}$ \\
Group $\mathrm{A}_{2}:$ Nonobese female & $\mathrm{ns}=$ & Not significant \\
Group $\mathrm{B}_{1} \quad:$ Obese male & $*=$ & $\begin{array}{l}\text { Significant at } \\
\mathrm{p}<0.05 \text { level }\end{array}$ \\
Group $\mathrm{B}_{2} \quad:$ Obese female & &
\end{tabular}

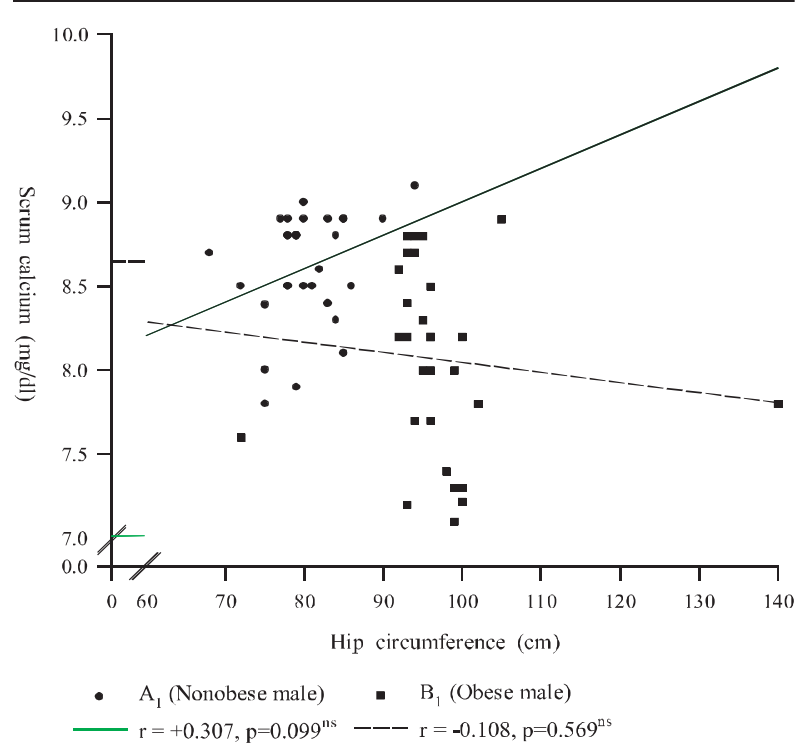

Fig.-3: Correlation of serum calcium with hip circumference in male

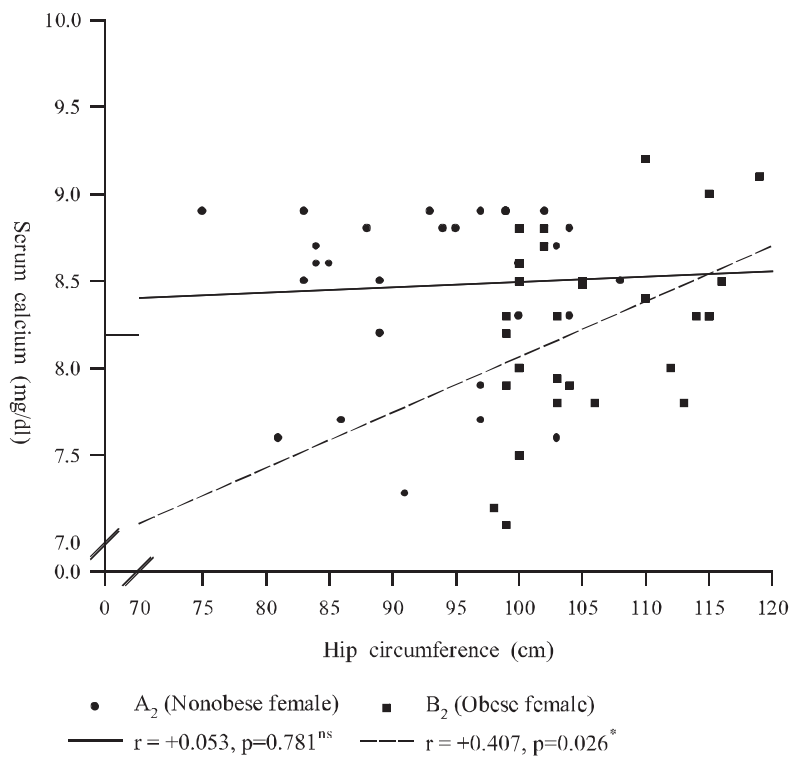

Fig.-4: Correlation between serum calcium \& hip circumference in female

\section{Discussion:}

In the present study, serum calcium level in obese female $\left(B_{2}\right)$ showed significant positive relationship of serum calcium with BMI ( $r=$ $+0.397, p=0.030)$ and Hip C $(r=+0.406, p=0.026)$. This may be described by the role of estrogen causing both pear shaped obesity in females and increased calcium absorption. ${ }^{10}$

Both male case and control groups $\left(A_{1} \& B_{1}\right)$ serum total calcium level showed statistically non-significant negative correlation with BMI. Both female case and control groups $\left(A_{2} \& B_{2}\right)$ serum total calcium level showed statistically non-significant positive correlation with BMI. Serum total calcium level showed statistically non-significant positive correlation with Hip $C$ in male and female control group $\left(A_{1} \& A_{2}\right)$.

Some of these findings were similar to the finings of Kamycheva, Sundsfjord and Jorde (2004) and Ahlstrom et al. (2009).

Kamycheva, Sundsfjord and Jorde (2004) showed serum calcium has a significant positive relation with BMI in both genders, the present study findings agreed with their findings in male cases but present study found statistically non-significant negative relationship in female obese cases.

Ahlstrom et al. (2009) observed a positive correlation between plasma calcium level and BMI. 


\section{Conclusion}

From the previous discussion it may be concluded that serum calcium level in obese female increases with BMI \& Hip circumference.

\section{References}

1. Lean MEJ, Han TS, Seidell JC. Impairment of Health and Quality of Life Using New US Federal Guidelines for the Identification of Obesity. Arch Intern Med 1999; 159: 837-843.

2. World Health Organization Certified [database on the internet]. Global strategy on diet, physical activity and health- Obesity and over-weight. [cited 2010 July 25]. Available from: http:// www.who.int/dietphysicalactivity/publications / facts/obesity/en [Accessed on 23.06.2011].

3. Harold C, Slavkin DDS. Obesity, brain and gonadal functions, and osteoporosis. J Am Dent Assoc 2000; 131(5): 673-677.

4. American Obesity Association [homepage on Internet]. Health effects of obesity. C-2000 [updated 2010 July 25]. Available from: http:// www.obesity.org/Health_Effects.htm [Accessed on 24.06.2011].

5. Champe PC, Harvey RA and Ferrier DR. Lippincott's Illustrated Reviews: obesity. $4^{\text {th }}$ ed.
USA: Lippincott Williams \& Wilkins; 2008. P. 354-355.

6. Norman J 2010, Hyperparathyroidism: Overactivity of the Parathyroid Gland. Endocrineweb [Internet].2010.[cited2010]. Available from: http://www.Endocrineweb.com [Accessed on 24.06.2011].

7. Ahlstrom T, Emil H, Anders L, Claes R, Lars L, Per H. Correlation between plasma calcium, parathyroid hormone (PTH) and the metabolic syndrome (MetS) in a community-based cohort of men and women.2009. Clin Endocrinol 2009; 71(5): 673-678.

8. Shi H, Norman AW, Okamura WH, Sen A \& Zemel MB. 1alpha,25-Dihydroxyvitamin D3 modulates human adipocyte metabolism via nongenomic action. FASEB J 2001; 15: 2751-2753.

9. Zemel MB, Shi H, Greer B, Dirienzo D and Zemel PC. Regulation of adiposity by dietary calcium. FASEB J 2000; 14: 1132-1138.

10. Gallagher JC, Riggs BL, DeLuca HF. Effect of estrogen on calcium absorption and serum vitamin D metabolites in postmenopausal osteoporosis. J Clin Endocrinol Metab 1980; 51(6): 1359-64. 